\title{
Recollection
}

\section{Witness the prosperity: 25 years of life science revival in Tsinghua University}

\author{
Zhirong Sun ${ }^{\bowtie}$ \\ School of Life Sciences, Tsinghua University, Beijing 100084, China \\ $凶$ Correspondence: sunzhr@mail.tsinghua.edu.cn
}

It's been over twenty-five years since I joined the Department of Biological Sciences and Biotechnology (DBSB) of Tsinghua University when it was re-established in September 1984. It started with almost zero to the nowadays well-known life science Eden in China. With the growing number of laboratories, buildings and publications and increasing international reputation, I have to say that it has been quite a journey and I'm very proud to be part of it since the very beginning.

Well, "the very beginning" might not be the right words to describe it. As a member of DBSB, and as the editor of The Commemorative Book of the Tenth Anniversary of DBSB ReEstablishment back in 1994, I have become more aware of the glorious history of the Department of Biology of Tsinghua University, the predecessor of DBSB. As one of the earliest Chinese institutions in life science area, the Department of Biology of Tsinghua was established in 1926. The department started quite small, with one full-time professor Shu-Peng Qian teaching Botany and two guest professors teaching Zoology and Comparative Anatomy. Only three students registered in the Department of Biology in the first year-the faculty-student ratio was pretty satisfying. Despite the small start, the Department of Biology had been moving forward with steady steps. More professors joined the department and more students became interested in biology. By 1936, the number of faculty members reached 14 , and the number of students reached 44 .

The building of the department (or "the Department Hall", as people would call it), a Western-style building constructed with the Rockefeller Group's donation and the University's fund, was completed in 1930. A considerable collection of lab equipments, animal and plant specimens, teaching models, books and journals, had been purchased and put into use. Even during the difficult years of the Anti-Japanese War, when all the best universities (including Tsinghua) in northern China were forced to move to Kunming and merged into the famous Southwest United University, the courses of the department was never stopped.

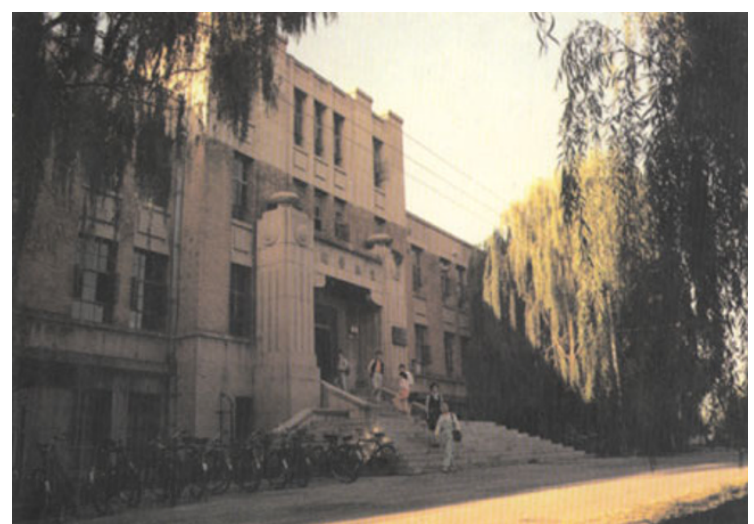

The "Department Hall". (from The Commemorative Book of the Tenth Anniversary of DBSB Re-Establishment)

However, in 1952, Chinese universities went through a series of adjustment and reorganization. Tsinghua University was considered a university of industrial technologies, so the Department of Biology was transferred to other universities. It was the end of the Department of Biology of Tsinghua University. During its twenty-six-year existence, the Department of Biology had trained hundreds of young people, many of whom later chose Biology as their life-time career. Thirty-six department alumni were selected as members of Chinese Academy of Sciences, the highest honor for scientists in China. Many alumni stayed in academia and became professors in universities where they spread their knowledge of life science to more young people.

For the next three decades since 1952, Tsinghua University had been focusing on technologies and engineering, 
and became the number one technological university in China. Meanwhile, tremendous progresses had been made in the life research area around the world, such as the discovery of DNA double helix structure in 1953 and the following breakthroughs in molecular biology and bioengineering. All of these had not raised much of awareness in Tsinghua until early 1980s, when Dr. Nan-Ming Zhao of Tsinghua visited several universities in the United States and Japan. Dr. Zhao, a nuclear physicist himself, was amazed to find that, in all the universities he visited, the biology departments (or schools) had the best resources-brand new laboratories, state-ofthe-art equipments, abundant funding, and the smartest people. The research works conducted in these labs were nothing like the traditional biological experiments that he would have imagined. In addition, he found that modern biology was a new area that required a great amount of knowledge of physics, chemistry and engineering, which was the advantage of Tsinghua University. Excited and inspired, he wrote a report about everything he learned about modern biology during his trip, and submitted to the university board. It turned out that he did the right thing at the right time, as the university was at a turning point and the leaders had been planning to restore the glory of art and sciences that Tsinghua had achieved before. To put a long story short, after three years of investigation, discussion and preparation, the Department of Biology was re-established in September 1984 with a new name: Department of Biological Sciences and Biotechnology (DBSB).

The re-establishment of the department was probably as challenging as the first time around, which meant starting from scratch. The first task was to recruit faculty. Fellow universities and institutes, such as Peking University and Institute of Biophysics of Chinese Academy of Sciences, were very supportive, and some professors decided to join the DBSB. Other faculty members were recruited within Tsinghua, from other departments such as Engineering Physics, Organic Chemistry, and Automation. Dr. Nan-Ming Zhao, who first suggested the re-establishment of the department, was recruited and appointed the vice dean. I was then a junior researcher at the Department of Automation. Just like any other young scientist, new ideas went through my mind everyday and I loved to talk about them with colleagues. So, one day after work, I ran into Dr. Zhao who lived in the same building with me, and chatted about my new idea of biological system engineering; at the end of that chat, I was invited to join the DBSB! That was the biggest turning point of my career and I am glad that I accepted the offer. The faculty recruitment went very well, and the department was lucky to have Prof. Mu-Ming Poo as the Dean. Prof. Poo was then a professor at Columbia University and had always been enthusiastic about promoting life science research in China. He worked part-time as the Dean without receiving salary from the university, and paid by himself for the flight tickets between Beijing and New York. He even bought quite a lot of books for the library of the department out of his own pocket. These contributions were very precious for the department at her infant age.

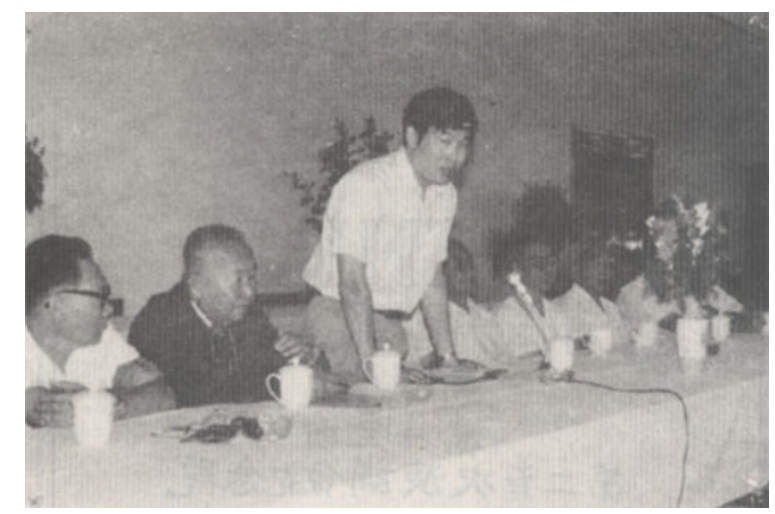

Prof. Mu-Ming Poo delivering a speech at the DBSB reestablishment ceremony. (from The Commemorative Book of the Tenth Anniversary of DBSB Re-Establishment)

In addition to faculties, the department also needed a physical location. The old "Department Hall" had been converted into a campus hospital after 1952. So we had to set up offices and labs in a place called "Building 36 ", which had been occupied as a medical ward for wounded Japanese soldiers during the war. With tremendous efforts from the department and the university, the "Department Hall" was back as the main building for biology people again. Currently this historic building becomes a symbol for life science in Tsinghua campus and is still in active use.

At the early time of re-establishment, there was no lab equipment; and the funds from the university to purchase instruments were very limited, so the department had to seek other resources, such as research funds from the Beijing Dongfeng Pharmaceutical Plant. In short, we went through quite a difficult time for the first few years. Fortunately, we did not have to worry about recruiting good students, as Tsinghua always had (and still has) the best ones in the country. Most of them were smart and eager to learn, and got inspired by the amazing world of biology everyday. With combined supports from inside and outside the university, high-quality faculty and first-class students, the department has been moving forward fast paced. Last year, twenty-five years after the re-establishment, the university decided to convert the much-expanded department into a school-the School of Life Sciences. The new Dean of the school, Dr. Yigong Shi, is an alumnus from Class 1984 (the first Class of DBSB), a returnee from Princeton University, and also a student of mine.

During the past twenty-five years, the Department of Biological Sciences and Biotechnology of Tsinghua University has cultured over one thousand undergraduate students and 
hundreds of graduate students. Most of them are now active researchers all over the world. More and more alumni come back to the department. They continue the responsibilities of us older generation, devoting themselves to their mother school and reproducing her glory. I am so proud of having been part of her and I will keep witnessing her prosperity. 